\title{
THE BEECHWOODS OF THE CENTRAL PREPYRENEES (SPAIN). A PRELIMINARY SURVEY FOR CONSERVATION
}

\author{
L. Villar \\ Instituto Pirenaico de Ecologia (CSIC), Apdo. 64, 22700 Jaca, Huesca, Spain
}

A. M. Romo

Institut Botànic, Avda. dels Muntanyans, Parc de Montjuic, 08038 Barcelona, Spain

$\&$

\author{
M. T. Perdigó \\ Departament de Botànica, Facultat de Biologia, Universitat de Barcelona, 08028 Barcelona, Spain
}

(Received 8 July 1987; revised version received 7 June 1992; accepted 4 January 1993)

\begin{abstract}
The southern limit of European beech Fagus forests in Spain follows the Pyrenees and the Cantabrian mountains. In the Central Prepyrenees, beech is often mixed with fir Abies alba-also at the southern limit of its range- and covers the slopes exposed to cloud, where it forms isolated relict deciduous forests among the submediterranean and more widespread Quercus faginea woodland. These forests are scattered over the sierras running west to east for $160 \mathrm{~km}$ through the provinces of Zaragoza, Huesca and Lérida.

A floristic and ecological study for conservation allows us to distinguish three types of beechwoods: (a) submediterranean forests with box Buxus sempervirens, growing on limestone or marls; (b) more or less isolated atlantic montane beechwoods, on eutrophic soils, and (c) acidophilous forests, over sandstones or other acidic soils. Most have been cleared or cut, not only for timber but also for grazing; in some cases Pinus sylvestris has spontaneously colonised the cleared areas and the former wood is able to regenerate; but in others the soil has been eroded, and regeneration of the beechwoods is inhibited, being replaced by submediterranean pastures or shrubs. At the present time, most of the forests are young, with trees 60-80 years old and only occasionally some up to 200 years.
\end{abstract}

Reafforestation was always with pines, but in many cases by opening up terraces-a very destructive procedure causing soil erosion-and with too many roads. Most of the forest belongs to the State, and the Regional Administration of Forestry (Aragon) is now studying their maintenance, first by the establishment of the Sierra de Guara Natural Park and also by declaring many 'protective forests'.

In this paper we study their present situation and

Biological Conservation 0006-3207/93/\$06.00 (C) 1993 Elsevier Science Publishers Ltd, England. Printed in Great Britain dynamics, emphasize their great ecological, landscape and didactic value and propose a number of beechwoods to be protected: Montsec, Aubenç and Malpás (Lérida); Gabardiella, Monte Peiró, Bonansa and La Garona (Huesca) and Puy Moné (Zaragoza).

\section{Resumen}

El límite sur del área continua de los hayedos europeos pasa en la Península Ibérica por el eje pirenaico-cantábrico. Particularmente, en el área prepirenaica central española, los hayedos muchas veces llevan abeto Abies alba (también en su limite meridional) y ocupan algunas laderas expuestas a las nieblas, formando manchas aisladas entre los bosques submediterráneos de Quercus faginea; tienen un carácter residual y salpican sierras que se extienden de $W$ a $E$ unos $160 \mathrm{~km}$ en las provincias de Zaragoza, Huesca y Lérida.

Un estudio florístico y ecológico con vistas a su conservación permite distinguir tres tipos de bosques: (a) hayedos submediterráneos con boj Buxus sempervirens. sobre sustratos calizos o margosos; (b) hayedos atlánticos montanos, muy aislados en el territorio estudiado, sobre suelos eutrofos, y (c) hayedos acidófilos, sobre areniscas pobres en bases. La mayoria de ellos se han aclarado y explotado, tanto para fines pastorales como forestales; en unos casos ello ha favorecido la entrada de pino silvestre Pinus sylvestris y el hayedo se puede recuperar; en otros el suelo se erosionó y la regeneración del hayedo es dificil, porque fue sustituido por comunidades de pasto o matorral submediterráneo. Buena parte de los bosques están 'rejuvenecidos', mostrando los árboles 60 a 80 años de edad; sólo algunas parcelas de 100 ha. poseen ejemplares de unos 200 años, muy viejos.

Las repoblaciones forestales se hicieron siempre con pinos y muchas veces los aterrazamientos contribuyeron a erosionar el suelo, tanto como los caminos forestales poco cuidadosos. La mayoria de estos bosques pertenecen al Estado y la Administración forestal regional (Aragón) 
se ha propuesto su mantenimiento y mejora, tanto a través de la figura legal de monte protector como en el recientemente declarado Parque Natural de la Sierra de Guara (Huesca).

Destacamos su estado de conservación y dinámica, su gran valor ecológico, paisajístico y didáctico, señalando también las mejores parcelas para su conservación: hayedos del Montsec, Aubenç y Malpás (Lérida); Gabardiella, Monte Peiró, Bonansa o La Garona (Huesca) y Puy Moné (Zaragoza).

Key words: Spain, Pyrenees, Fagus, forest dynamics, conservation

\section{INTRODUCTION}

Beech Fagus sylvatica is probably the most important deciduous tree species in Europe. Palynological data show that after the ice age it spread through the Cantabrians, Pyrenees and Prepyrenees during the subatlantic period, approximately 4000 years BP (Jalut, 1988). Its range before the impact of man was therefore more or less continuous from Galicia to Aragón and Catalonia, particularly in the humid mountainous areas influenced by an atlantic climate (Montserrat, 1966; Rivas Martínez, 1987).

In particular, the beech forests in the central Prepyrenees (Fig. 1), which is now dominated by a submediterranean climate, have a relict character, being restricted either to the north slopes exposed to cloud or to the bottoms of narrow valleys, in a shady local climate. In the western aragonese part of this area (Zaragoza and Huesca provinces), beech can be dominant in the tree layer, but in the central-eastern parts of Huesca and Lérida provinces it is mixed with silver fir Abies alba, or with other deciduous trees such as largeleaved lime Tilia platyphyllos, italian maple Acer opalus, hazel Corylus avellana, elms and oaks.

All over the prepyrenean zone, these beech-fir woods are at the southern limit of their range, isolated and perhaps not well-adapted to the present-day climate. They are thus very sensitive to exploitation and have been greatly modified by timber and fuelwood extraction, or by grazing and cultivation, and in some cases completely destroyed. Pinus sylvestris has thus been able to invade in some places impeding the regeneration of Fagus, so that mixed beech-pine forests are now frequent.

Nevertheless, as indicated by Villar (1986), the conservation of the remaining forests is of great importance, not only because they protect isolated pockets of atlantic plant and animal populations within an otherwise submediterranean and mediterranean climate, but also to maintain soil fertility, the hydrological equilibrium, and as a defence against catastrophic fires.

We comment in this paper on the structure, floristics, dynamics, land use, and ecological value of these interesting deciduous woods and on some strategies for future conservation management.

Nomenclature follows Tutin et al. (1964-80).

\section{DESCRIPTION OF THE STUDY AREA}

The prepyrenean sierras run mainly west to east, with beech occurring normally on steep north-facing slopes, from the river Arga (Zaragoza) to the rivers Noguera Ribagorzana and Segre (Huesca and Lérida). These forests are scarce on the southern sierras of the Catalan Prepyrenees (Aubenç, Mitjana, Montsec, Fig. 2), occurring only in very shaded and wet places, but become increasingly more frequent to the north and west, between 1100 and $1700 \mathrm{~m}$, in the mountains of Sant Gervás, Serra de Cis, the Turbón massif, etc. In Huesca province, beechwoods also occur in some gullies such as La Garona and on the north side of the Sierra of Campanué.

In the Cinca-Ara valleys, Fagus grows in the shadow of the Peña Montañesa, Navain and Canciás, between Sarvisé and Fanlo, either as a single species or mixed with fir and other species. There are particularly fine beechwoods in the Gállego river area, at Oturia and in the Aragon river valley on Oroel and San Juan de la Peña (Fig. 3).

In the mountains between Huesca and Jaca, beech is found in some places on the Sierras of Guara, Gratal and Santo Domingo (Fig. 4). At the last site, in the Puy Moné area, it spreads over the gentle mountain tops into an evergreen forest of Quercus rotundifolia (Villar et al., 1990).

In the Prepyrenees, beechwoods are generally isolated among the dominant forests of portuguese oak Quercus faginea, and surrounded by shrub formations of box Buxus sempervirens, between 900-1000 and 1700 m altitude (Montserrat, 1971; Rivas Martínez, 1987). The most southerly localities in the study area are in the Sierra of Gabardiella, near Guara (Huesca) and the Serrat de la Font Freda, Montsec d'Ares (Romo, 1989). Further to the east, in the Sierra of Boumort and elsewhere, beech is absent, perhaps due to the increasing continentality. Here the shady and damp sites are covered by dense formations of Corylus avellana (Carreras \& Ninot, 1986; Molero \& Romo, 1988).

\section{Climate}

The climate of this area can be divided into two types: occidental, affected by the oceanic climate of the Western Pyrenees, and oriental, protected from the air masses circulating from the Atlantic and dominated by a submediterranean climate. There are unfortunately no climatic records from the beechwoods themselves, but the stations of Jaca and Pont de Suert, for which ombrothermic diagrams have been drawn, provide a representative series of the two types.

Jaca, on the Aragon river, at $820 \mathrm{~m}$, not far from the San Juan de la Peña and Oroel fir-beech forests, had an average annual rainfall between 1970 and 1987 of $880 \mathrm{~mm}$ (Fig. 5). Winter is the wettest season (28.3\%), followed closely by spring $(26 \cdot 2 \%)$ and autumn $(25.8 \%)$. In addition, the summers are not dry, because of frequent storms, which are especially severe in July and August. The annual average temperature is $10 \cdot 7^{\circ} \mathrm{C}$. Frosts occur in December and continue until February, 


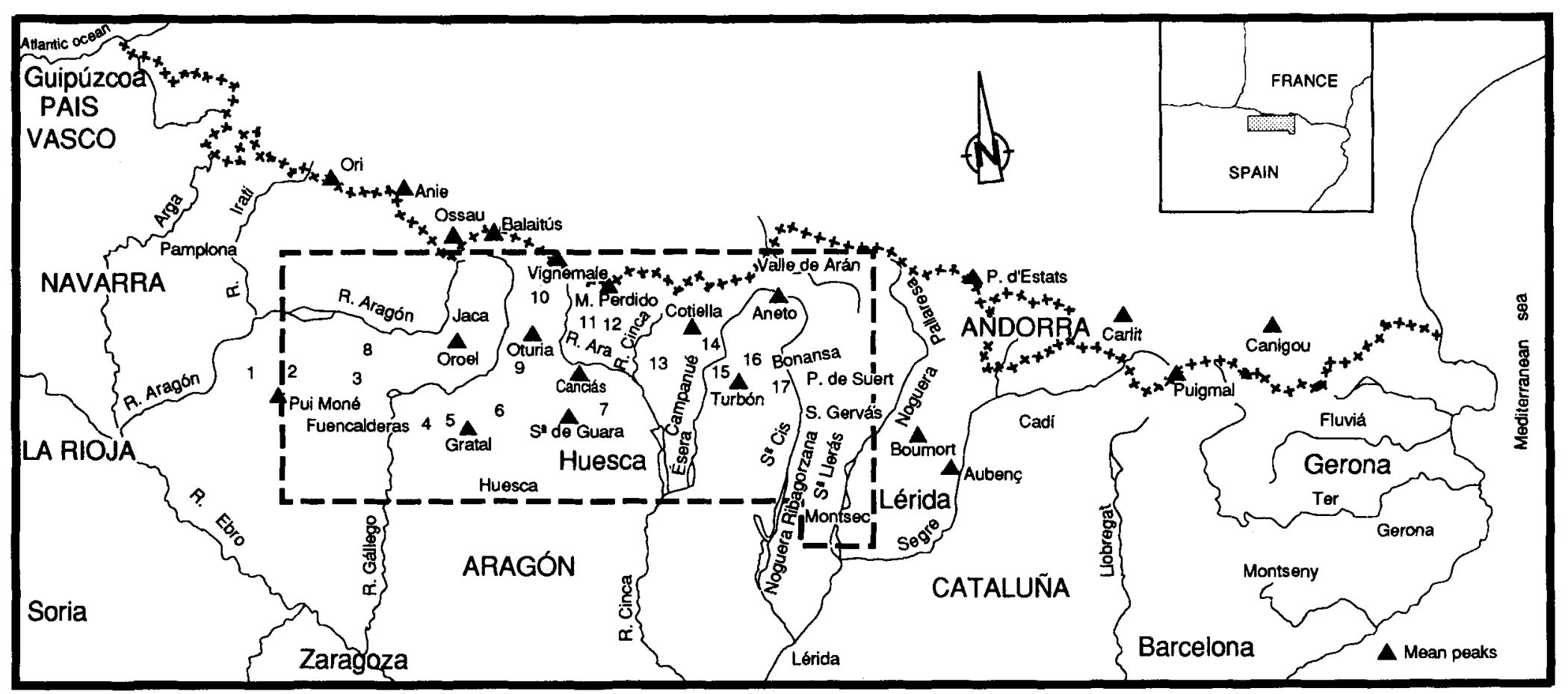

Fig. 1. The Spanish Pyrenees, showing the main localities and massifs cited in the text; - - , study area. Other numbered sites containing Fagus: 1 . Petilla de Aragón; 2. Sierra de Santo Domingo; 3. Sierra de Salinas; 4. Sierra Caballera; 5. Monte Peiro; 6. Sierra de Gabardiella; 7. Sierra de Sivil; 8. San Juan de la Peña; 9 . Sierra de Picardiello; 10. Montes de Yésero-Linás; 11. Sarvisé-Fanlo; 12. Sierra de Bolave; 13. Peña Montañesa-Sierra Ferrera; 14. Barbaruéns; 15. Campo-Seira; 16. San Feliu-La Muria and 17. Obarra. 


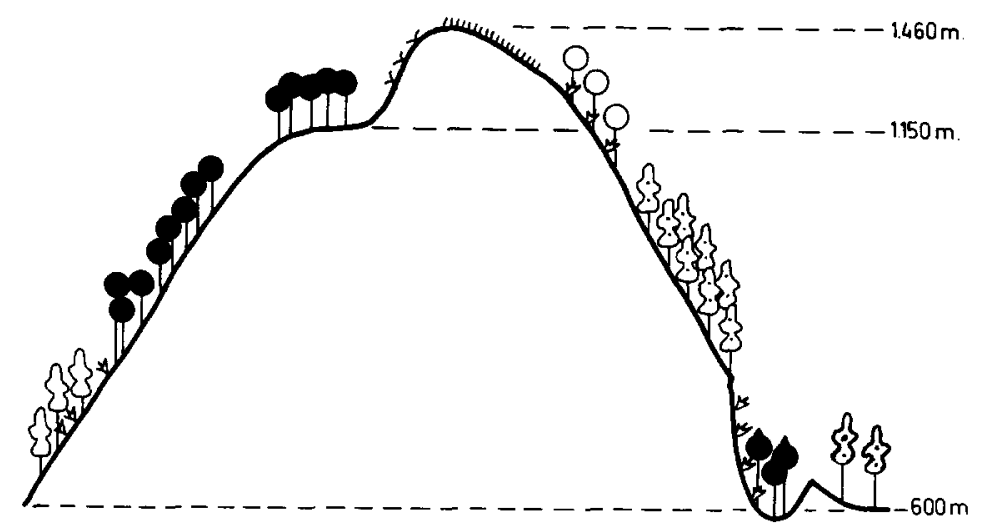

Fig. 2. Montsec d'Ares (Lérida province). $\$$, Quercus gr. faginea-cerrioides; $\uparrow$, Fagus sylvatica; $\uparrow$, Quercus rotundifolia; $\uparrow$,

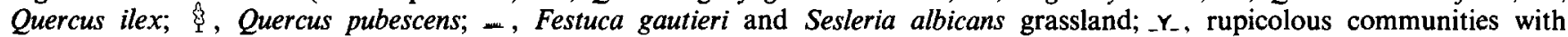
Saxifraga longifolia and Ramonda myconi; $x$, Buxus sempervirens.

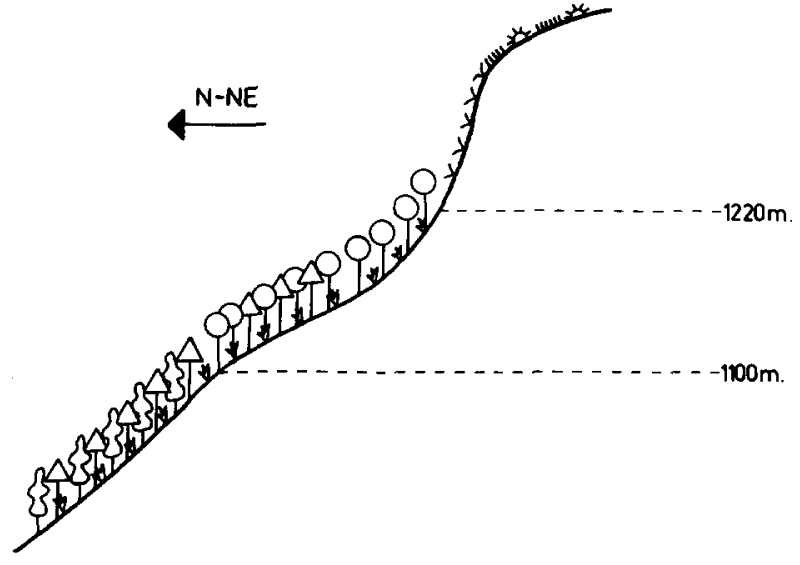

(a)

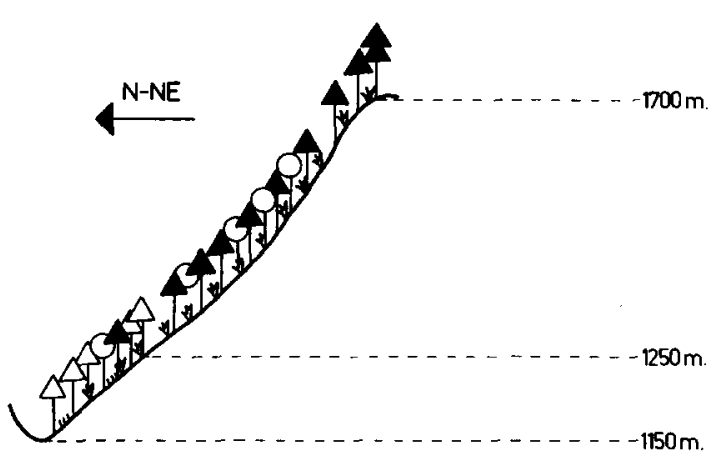

(b)

Fig. 3. (a) North slope of San Juan de la Peña Massif, Jaca (Huesca province); (b) north slope of Mont Oroel, Jaca (Huesca). Symbols as in Fig. 2; $\uparrow$, Abies alba; $\uparrow$, Pinus sylvestris; \&, Pinus uncinata; 此, Echinospartum horridum.

but there is also a high probability of ice in OctoberNovember and March-May. The coldest month is January and the hottest August.

In the eastern part, Pont de Suert, in the Noguera Ribagorzana valley near the Sierra de Sant Gervàs and Bonansa forests, is situated at $838 \mathrm{~m}$. Here the average rainfall is $1003 \mathrm{~mm}$, with two rainy periods, due to the mediterranean influence-spring (May maximum), and autumn (September-October). Because of the continentality winter is the driest season. As at Jaca, the summer is not dry, with storms in many places. The average temperature is similar, but the frost period is shorter than in Jaca, and July is the hottest month (Fig. 5).

However, over and above these climatic records cloud often lies on the north side of Oroel and elsewhere between 1200 and $1700 \mathrm{~m}$, precisely the range of beech and fir. The major part of these sierras are therefore condensation areas, and we estimate that the beech-and-fir microclimate receives $1000 \mathrm{~mm}$ precipitation per year. 'Hidden precipitation' (Montserrat, 1986) must therefore play an important role on these slopes having northern or northwestern exposures, permitting the beech to exist in drier conditions than usual. In this sense, Thiebaut $(1979,1984)$ pointed to the existence of ecotypes of Fagus well-adapted to these submediterranean climates and the hydric stress involved. In addition, the southern populations of beech produce many more shoots on the cut stumps than in atlantic populations.

\section{Soils}

In the Prepyrenees beech forests are established on four types of lithological facies (Soler \& Puigdefábregas, 1972): subpyrenean clays and sandstones; limestone; conglomerates with a calcareous binding material; and conglomerates with a siliceous cement. All but the last of these are base-rich. Many of the soils are of colluvial origin, including stones fallen from the cliffs. In spite of this origin, they can be deep, up to $1 \mathrm{~m}$ or more. Beech, fir and other trees have contributed to the formation of brown fertile soils, a large proportion of the trunks being curved at the base, due to solifluction.

A preliminary study carried out by Bresset (1990) demonstrated slightly acid soil on the clay and sand- 


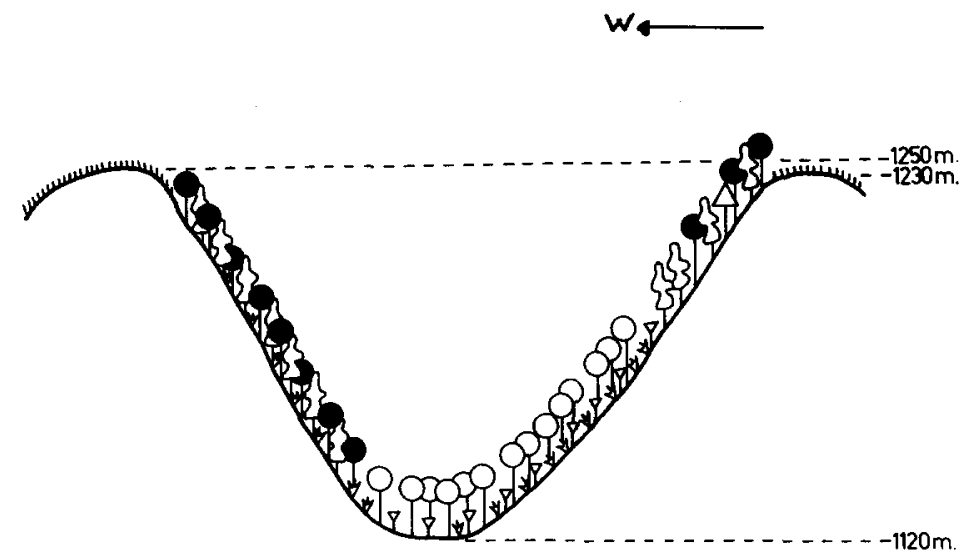

Fig. 4. Barranco de Val, Sierra de Santo Domingo, Luesia, (Zaragoza province). Symbols as in Figs 2 and 3; 4 , Pinus sylvestris; - Mesobromion grassland; $\mathrm{P}$, Ilex aquifolium.

stone 'flysch' of the Oturia massif, with a pH of $6-6 \cdot 7$, a limey or argillaceous-limey texture and compact structure. The $\mathrm{C} / \mathrm{N}$ ratio varied from 17 to 29 and the corresponding humus can be classified as 'forest mull' or 'moder mull'. In spite of the low carbonate content in the surface levels, we found very few acidophilous species.

In contrast, the conglomerates with a calcareous binding material sampled from San Juan de la Peña gave leached brown soils with $\mathrm{pH}$ values of about 5 , as well as a sandy-lime texture. Here the decomposition of organic matter is intermediate (C/N: 17) and the humus becomes an 'acid mull'. On this mountain, the Abies forest is rich in acidophilous plants, as are the beech- woods which colonise the siliceous conglomerates of Bonansa, further to the east.

\section{METHODS}

We selected about $50100-400 \mathrm{~m}^{2}$ stands scattered in the Prepyrenean sierras over a distance of $150 \mathrm{~km}$ in which the floristic composition of the ground vegetation and tree layers was studied during 1987 and 1988. An estimated index of cover abundance was noted for each species $(1: 0-20 \%$ cover; $2: 21-40 \% ; 3: 41-60 \%$; $4: 61-80 \% ; 5: 81-100 \%)$. More detailed information can be found in Villar et al. (1990). The circumference (20 individuals per stand) and age (total of 40 individuals)
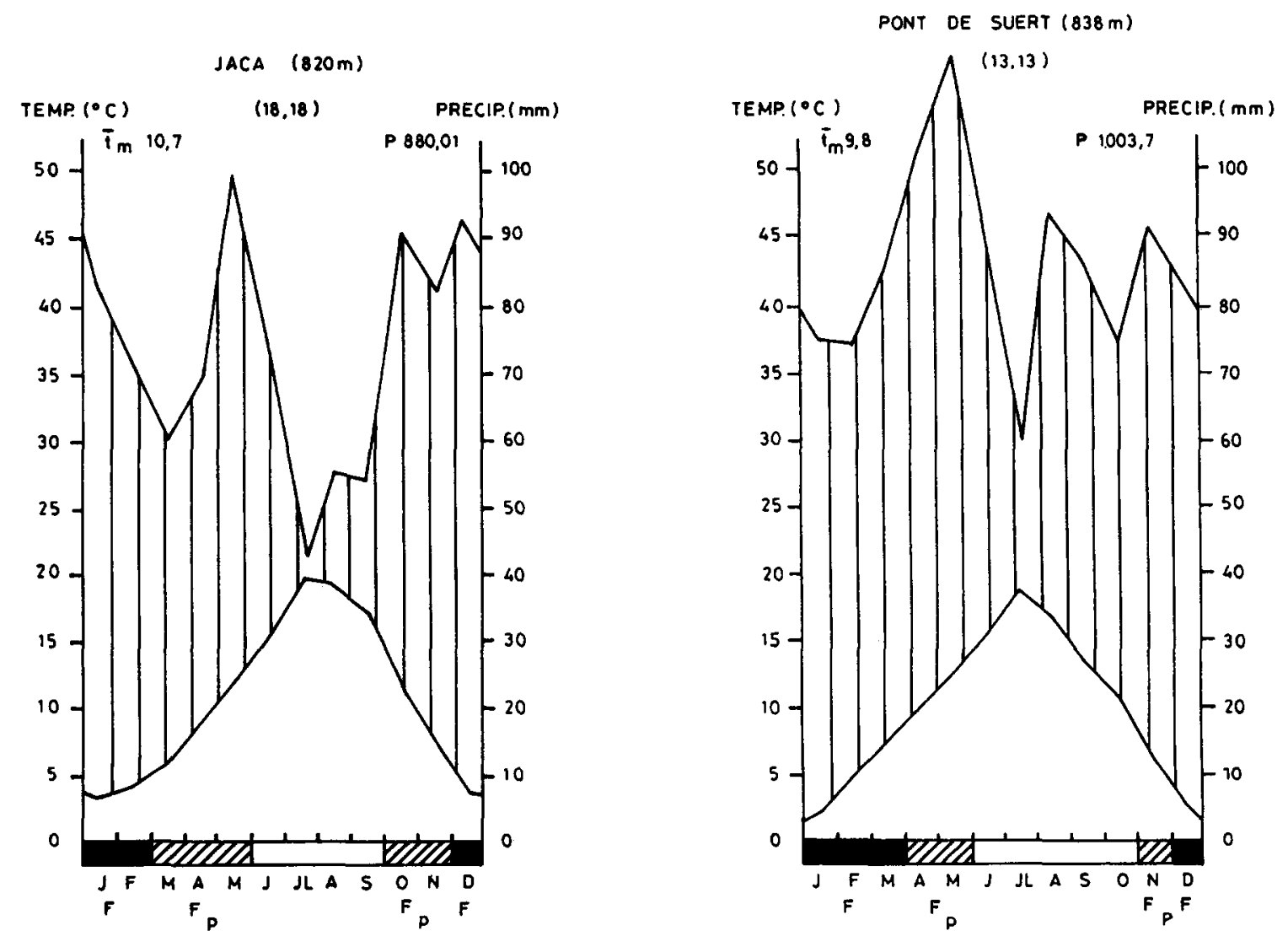

Fig. 5. Ombrothermic diagrams of Jaca (Huesca) and Pont de Suert (Lérida). The number of years is indicated in parenthesis (18 for Jaca and 13 for Pont). Months and period of frost $(F)$ and probable frost $(\mathrm{Fp})$ are shown on the horizontal axis. 
of the main trees were also measured. A vegetation map of beech and fir woods was prepared from aerial photographs and ground surveys.

\section{RESULTS}

\section{Forest structure and composition}

From a phytosociological point of view, the prepyrenean beechwoods are assigned to the submediterranean community Buxo-Fagetum (Villar et al., 1988). There are three layers:

(1) a mono-specific arboreal layer, reaching 15 to $25-30 \mathrm{~m}$ in height and generally not forming a closed canopy, as much due to climatic conditions as to exploitation.

(2) a dense understorey vegetation, especially when the woodland has been thinned or grazed, very rich in Buxus sempervirens and numerous plants also found in the Quercus faginea-cerrioides or pubescens oakwoods (Table 1).

(3) Further north and west into the Pyrenees, the shrub layer becomes scarcer, remaining only in the forest margins or clearings. Here the litter layer is thicker and atlantic or central european species appear, particularly early-flowering plants such as Scilla lilio-hyacinthus and Covallaria majalis. Compared with atlantic beechwoods, the scarce fern populations associated with this community are represented by Dryopteris filix-mas, Athyrium filix-femina or, only seldom, by Polystichum setiferum isolated in unexploited ravines, often in the shade of Tilia, Acer, Ulmus, etc. In some places Vaccinium myrtillus, Calluna vulgaris or Genista pilosa occur on the acid sandstone soils. Abies alba, the largest tree species in the Pyrenees, is found locally on deep and wet soils, here at its southern limit. According to the management regime, Ilex aquifolium and Pinus sylvestris may colonise the clearings.

A clear predominance of young trees was found in the sites studied, as is normal in regenerating woodland. In these exploited communities, most of the trees are 60 80 years old, their trunks reaching a circumference of $50-70 \mathrm{~cm}$. An exception is the beechwood at Monte Peiró, not far from Arguis (Sierra de Gratal, Huesca), which contains a group of very old specimens (nearly 200 years), with magnificent trunks $300 \mathrm{~cm}$ in circumference.

On the basis of over 50 samples, the number of vascular species in an area of about $100 \mathrm{~m}^{2}$ fluctuated between 13 and 37 , but mostly amounted to 15-25. In general, species richness increased in the more modified woods, while well-conserved stands with close canopy and dense shade had a low diversity. Among these plants, $50 \%$ are euro-siberian, $17 \%$ circumboreal, $12 \%$ submediterranean, $11 \%$ atlantic or subatlantic; the remaining $10 \%$ belongs to other groups.

\section{History of exploitation}

The human population of the prepyrenean zone was stable from the Middle Ages to the 18th century and reached a peak in the second half of the 19th century (García-Ruiz, 1976). From 1900 it decreased more or less slowly until 1960, when suddenly the area became depopulated or abandoned.

Table 1. Floristic composition of the beechwoods

\begin{tabular}{|c|c|c|c|c|c|}
\hline $\begin{array}{l}\text { Main } \\
\text { forest types }\end{array}$ & Trees & $\begin{array}{c}\text { Mean cover } \\
(\%)\end{array}$ & Shrubs & $\begin{array}{c}\text { Mean cover } \\
(\%)\end{array}$ & $\begin{array}{l}\text { Herbs (generally } \\
\text { low cover) }\end{array}$ \\
\hline $\begin{array}{l}\text { Beechwood with box } \\
\text { (basic soils, } 880 \\
1510 \mathrm{~m} \text { altitude }\end{array}$ & $\begin{array}{l}\text { Fagus sylvatica } \\
\text { Quercus faginea } \\
\text { Acer opalus } \\
\text { Tilia platyphyllos } \\
\text { Sorbus aucuparia } \\
\text { Sorbus aria } \\
\text { Sorbus torminalis } \\
\text { Taxus baccata } \\
\text { Pinus sylvestris }\end{array}$ & $\begin{array}{c}80-100 \\
\text { r } \\
\text { s } \\
10 \\
s \\
s \\
\text { r } \\
10 \\
\text { r }\end{array}$ & $\begin{array}{l}\text { Buxus sempervirens } \\
\text { Corylus avellana } \\
\text { Lonicera xylosteum } \\
\text { Daphne laureola } \\
\text { Ipex aquifolium } \\
\text { Rosa canina } \\
\text { Crataegus monogyna }\end{array}$ & $\begin{array}{l}60 \\
20 \\
\mathrm{~s} \\
\mathrm{~s} \\
\mathrm{~s} \\
\mathrm{~s} \\
\mathrm{~s}\end{array}$ & $\begin{array}{l}\text { Hepatica nobilis } \\
\text { Viola riviniana } \\
\text { Ranunculus nemorosus } \\
\text { Euphorbia amygdaloides } \\
\text { Hedera helix } \\
\text { Fragaria vesca } \\
\text { Helleborus foetidus } \\
\text { Primula vulgaris } \\
\text { P. veris ssp. columnae } \\
\text { Neottia nidus-avis }\end{array}$ \\
\hline $\begin{array}{l}\text { Beechwood with fir } \\
\text { (acid or neutral soils, } \\
1200-1500 \mathrm{~m} \text { ) }\end{array}$ & $\begin{array}{c}\text { F. sylvatica } \\
\text { locally } \\
\text { Abies alba } \\
\text { locally }\end{array}$ & $\begin{array}{l}40 \\
20 \\
60 \\
80\end{array}$ & $\begin{array}{l}\text { Buxus sempervirens } \\
\text { Daphne laureola }\end{array}$ & $\begin{array}{c}30 \\
\mathrm{~s}\end{array}$ & $\begin{array}{l}\text { Scilla lilio-hyacinthus } \\
\text { Galium rotundifolium } \\
\text { Carex ornithopoda } \\
\text { Cephalanthera damasonium } \\
\text { Oxalis acetosella } \\
\text { Galium odoratum } \\
\text { Luzula sylvatica } \\
\text { Carex digitata }\end{array}$ \\
\hline $\begin{array}{l}\text { Acidophilous beechwoods } \\
\text { (acid sandstone soils, } \\
1400-1700 \mathrm{~m} \text { ) }\end{array}$ & Fagus sylvatica & 100 & $\begin{array}{l}\text { Vaccinium myrtillus } \\
\text { Genista pilosa } \\
\text { Calluna vulgaris }\end{array}$ & $\begin{array}{c}20 \\
\mathrm{r} \\
\mathrm{s}\end{array}$ & $\begin{array}{l}\text { Deschampsia flexuosa } \\
\text { Helleborus viridis spp. occi- } \\
\quad \text { dentalis } \\
\text { Luzula nivea } \\
\text { Veronica officinalis } \\
\text { Carex digitata } \\
\text { Oxalis acetosella }\end{array}$ \\
\hline
\end{tabular}

r, rare; s, scarce. 
The beech and fir forests were used by local people for charcoal and firewood, and also for timber. The taller trunks were floated downriver to the Ebro valleyespecially fir for use in the construction industry. In addition, the need for grazing land for local herds or transhumant flocks passing along the paths and crests from the plains of Lérida and Huesca led to forest clearance. In this way, the mature beechwoods of this part of the Prepyrenees have been gradually destroyed, leaving only fragments of the great original forests, usually in the more inaccessible areas.

Unfortunately the last remnants of the former forests have recently (1950-80) been subjected to 'normal' forest management for timber. New forest paths and tracks have been cut, using heavy machinery which results in soil erosion and solifluction. In addition, there is historic evidence of accidental or provoked forest fires from the middle of the last century until the present day and in many cases the beech or fir woods have never recovered. Nowadays, only a place name or some isolated trees growing on denuded and stony soil testify to the existence of an ancient forest.

Although there are still some well-managed forests, as for instance in the Sierra of Santo Domingo, nowadays most of the pure stands of beech and fir have been replaced by mixed populations of beech and pine or fir and pine. Pine establishes spontaneously, thanks to its heliophilous character, or is planted. In extreme cases, thoughtless exploitation has completely destroyed beechwoods with a poor capacity for regeneration, for example at Malpás, Turbón, Guara and Bonés.

\section{Forest dynamics}

Table 2 summarises the principal forms of retrogression in the prepyrenean beechwoods in relation to soils and other ecological factors.

\section{Vegetation change on acid soils}

On acid soils-sandstones or conglomerates of sandy matrix - destruction of the beechwood is followed by a Calluna vulgaris heath, together with Pteridium aquilinum, Viola canina and Lathyrus linifolius. After intensive grazing, the heath is transformed into a mesophytic pasture of Bromus erectus, which gives way to a pasture of acidophile annuals if erosion occurs.

Edaphic acidification can occur after autumn and winter rains as a result of the leaching of calcareous soils, on which Calluna may even establish (e.g. on Oroel). On marls, e.g. San Juan de la Peña and Santo Domingo, this process allows the colonisation of a particular heath community of Erica vagans, Genista occidentalis and Helictotrichon cantabricum, mixed with Brachypodium pinnatum and related pasture grasses.

\section{Vegetation change on calcareous soils}

On lime, the predominant soil type in the Prepyrenees, box is very common in beech and fir woods, forming a dense scrub with other shrubs typical of Quercus pubescens woodland. Submediterranean pastures of Aphyllanthes monspeliensis and Lavandula angustifolia subsp. pyrenaica (Aphyllanthion) can be found according to the degree of dryness or intensity of burning and grazing (Bolòs \& Montserrat, 1984). If the microclimate is cooler and the soil well-conserved, mesophile pastures of Bromus erectus (Mesobromion) occur.

This last type of pasture can be also achieved in the shady areas after fir or beech forests have been cleared, passing through a scrub of Rubus idaeus and Sambucus racemosa. Even in such limestone areas (e.g. Canciás), the destruction of the forest community and loss of fertility can lead to the establishment of discontinuous or pioneer pastures of Festuca gautieri, together with Saponaria caespitosa and Echinospartum horridum, both, oro-mediterranean endemics (Montserrat et al., 1984).

Sporadically, on some high depressions of the Canciás and Guara where the soil is deep and snow lies for long periods, the clearings in the beech or fir forests are colonised by an oro-atlantic pasture of Nardus stricta which in the prepyrenean area must be considered as a relict.

\section{REAFFORESTATION AND CONSERVATION}

In the Prepyrenees reafforestation started in 1910, intensified between 1950 and 1960 and reached a maximum in the 1970s (García-Ruiz, 1976; Chauvelier,

Table 2. Dynamics of the beechwoods

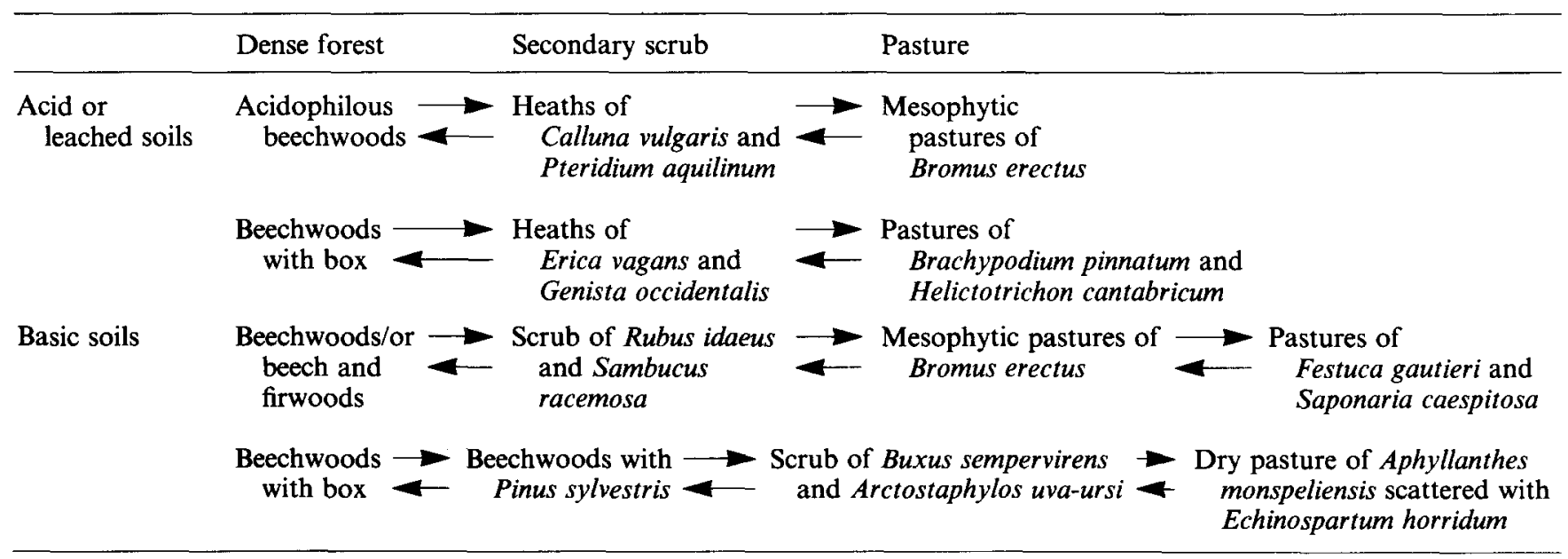


1990). On the Catalan side Pinus sylvestris was used, but in the Aragón region this species covered only $45 \%$ of the area, compared with 55\% Pinus nigra subsp. nigra. Trees planted more than 30 years ago, by hand or ploughing by means of oxen, have grown fairly well and forms woods which-if they are not burnedrepresent a first step towards mature woodland.

Recently, however, reafforestation has been carried out with heavy machinery, making terraces on the slopes on which pines are then planted. These activities destroy the existing vegetation and disturb the soil, which becomes eroded and is lost (Villar, 1981; Baulies $\&$ Romo, 1988). Moisture and water retained on the terraces do nothing to compensate for the general increase of scoured out mud or disturbance to the soil structure (Alberto et al., 1989). The regeneration of the ancient forest is thus in grave danger, and some springs have dried out after felling, for example in Oroel and Turbón.

Until recent times, people did not pay much attention to the conservation of the Spanish beechwoods, perhaps because they are situated in the Pyrenees, a mountain range considered to be a 'forest paradise' compared with the dry and mediterranean part of the country. Moreover, for many landowners (private, local councils or state), forests were seen as an exploitable resource, at least until 20 years ago, always available for communal and personal needs.

Nevertheless, following socio-economic changes such as the very marked reduction in livestock, agricultural abandonment and tourist improvements people are increasingly asking for the conservation of the beech woods at their southern limit, together with the flora, fauna and soils they conserve.

Without doubt, it is time to replant with Fagaceae (oak, beech) or with silver fir, following ecological criteria, and bearing in mind the restoration of the hydrological balance of the slopes and buffering soil erosion. Such a procedure has been initiated recently in the province of Navarra and should be done throughout the Prepyrenees. In the context of the objectives of the European Community, forestry should not be directed only towards production, but to increasing the stability of mountain ecosystems. This is even more important in the Central Prepyrenees, as yet unaffected by acid rain so that their forests are in a healthy state.

We consider that conservation effort must be focused on the following woods:

(a) beechwoods at Montsec and Aubenç (Lérida province), Gabardiella (Huesca) and Puy Moné (Zaragoza), as they are the most southerly examples.

(b) beechwoods of Malpás-Montiberri (Sant Gervàs, Lérida) and Monte Peiró (Huesca), as the best examples on limestone soils, and Bonansa (Sierra de Cis, Huesca), the only forest well-conserved on sandstone.

(c) La Garona and Irués beechwoods (Cotiella massif, Huesca), which represent an enclave of atlantic plants in a continental climate.

\section{DISCUSSION}

Although faunistic studies are needed and many human activities threaten these forests, the prepyrenean beechwoods have already been mapped on a scale of 1:50000 (Romo, 1986; Villar et al., 1990) and sufficient floristic and ecological data are available for use by the nature conservation authorities.

For instance, some endemic plants of the Pyrenees and Cantabrian mountains such as Ranunculus gouanii (Canciás, Oturia), or species exclusive to the Pyrenees, such as the Gesneriaceae Ramonda myconi, will surely profit from the 'protection' of the beechwoods and the shady and cool mossy rocks or cliffs in and around them (Sant Gervàs, Oroel, Gratal, Loarre, etc.). Ramonda in fact reaches its western limit in the beech and fir wood of San Juan de la Peña, near Jaca.

Some enclaves in the beech forest actually conserve several populations of 'atlantic' species at the southern limit of their range, such as Scilla lilio-hyacinthus (Canciás, Cotiella, Gratal, etc.), Phyllitis scolopendrium (Cotiella), Pulmonaria affinis (Oturia), Meconopsis cambrica, Ranunculus platanifolius, Paris quadrifolia or Allium ursinum, the last being very rare in the region and found only in the Sierra de Santo Domingo.

The regional authority of Aragón, in collaboration with the Consejo Superior de Investigaciones Cientificas, in 1988 financed an ecological and vegetation study of the prepyrenean beech woods as a basis for conservation and in February 1991 declared the Sierra de Guara as a Natural Park (the regional equivalent of National Park). The conservation of the beechwoods in the Aragonese area can therefore be viewed with some optimism. Moreover, many of the forests involved may be conserved as 'protective woodland' ('monte protector') a well-defined legal status in Spain's principal forest law (Anon., 1962). This action is made easier since most of the prepyrenean fir and beech woods are under the jurisdiction of the forestry administration.

In the case of private or communal forests, the autonomous authorities can establish a number of measures (subsidies, fiscal privileges, grants for infrastructures, etc.) to compensate the owners for the reduction in profits arising out of managing the woodland for conservation. This system has already been tested in Navarra, and without doubt could be partially supported by the state or EC protection programmes.

\section{ACKNOWLEDGEMENTS}

We would like to thank the research projects 'Estudio sobre los hayedos prepirenaicos aragoneses: flora, vegetación cartografia y valor ecológico' (Diputación General de Aragón and Consejo Superior de Investigaciones Científicas) and 'Estudios sobre flora y vegetación del Prepirineo central español' (Comision Interministerial de Ciencia y Tecnología) for financial support. We are also grateful to Rita Duffey for the translation and correction of the text to English and to J. A. Sesé for his help in preparing Fig. 1. 


\section{REFERENCES}

Alberto, F., García-Ruiz, J. M. \& Puigdefábregas, J. (eds) (1989). Evolución ecológica de las áreas reforestadas en el Pirineo Aragonés. Informe realizado por el CSIC para la Diputación General de Aragón. Instituto Pirenaico de Ecologia, Jaca (Unpublished report).

Anon. (1962). Ley y Reglamento de Montes. Ediciones del BOE, Madrid.

Baulies, X. \& Romo, A. M. (1988). Valoració ecològica de les repoblacións en terrasses al Pallars. Collegats, 2, 71-77.

Bresset, V. (1990). Première note sur l'étude synécologique des hetraies-sapinières jacetanes. Botánica pirenaicocantábrica, Monografias Inst. Pir. Ecología, 5, 497-520.

Carreras, J. \& Ninot, J. M. (1986). Sobre les avellanoses als Pirineus catalans. Collect. Bot., 16(2), 407-13.

Chauvelier, F. (1990). La repoblación forestal en la provincia de Huesca y sus impactos geográficos. Colección de Estudios Altoaragoneses, 34. Huesca.

de Bolòs O. \& Montserrat, P. (1984). Datos sobre algunas comunidades vegetales, principalmente de los Pirineos de Aragón y de Navarra. Lazaroa, 5, 89-96.

García-Ruiz, J. M. (1976). Modos de vida y niveles de renta en el Prepirineo del Alto Aragón occidental. Monogr. Inst. Estud. Pir., 106. Jaca.

Jalut, G. (1988). Les principales étapes de l'histoire de la foret pyrénéenne française depuis 15000 ans. In Homenaje a Pedro Montserrat. Monogr. Inst. Pir. Ecologia, 4, 609-15.

Molero, J. \& Romo, A. M. (1988). Vegetación forestal del Macizo del Boumort. VIII Jornadas de Fitosociología, Los bosques y su conservación, Málaga, 22-24 September 1988 (unpublished).

Montserrat, J. M. (1986). Flora y vegetación de la Sierra de Guara (Prepirineo Aragonés). Naturaleza en Aragón, 1. Zaragoza.

Montserrat, P. (1966). La vegetación de la Cuenca del Ebro. P. Cent. pir. Biol. exp., 1(5), 1-22.

Montserrat, P. (1971). La Jacetania y su vida vegetal. Caja de Ahorros de Zaragoza, Aragón y Rioja, Zaragoza.

Montserrat, P. (1986). Los abetales jacetanos de Oroel y San Juan de la Peña. Colloque International de Botanique Pyrénéenne, 93-97. Université Paul Sabatier, Toulouse.
Montserrat, P., Montserrat, J. M. \& Montserrat, G. (1984). Estudio de las comunidades de Echinospartum horridum en el Pirineo español. Acta biol. mont., 4, 249-57.

Rivas Martínez, S. (1987). Memoria del Mapa de las Series de Vegetación de España. Escala 1:400.000. ICONA, Madrid.

Romo, A. M. (1986). Estado actual de la cartografia de la vegetación en los Prepirineos centrales catalanes. Colloque International de Botanique Pyrénéenne, 315-23. Université Paul Sabatier, Toulouse.

Romo, A. M. (1989). Flora i vegetació del Montsec, Prepirineus catalans. Arx. Sec. Ciències, 90. Institut d'Estudis Catalans, Barcelona.

Soler, M. \& Puigdefábregas, C. (1972). Esquema litológico del Alto Aragón occidental. Pirineos, 106, 5-15.

Thiebaut, B. (1979). Etude écologique de la hetraie dans l'arc montagneux nord-méditerranéen de la Vallée du Rhone à celle de l'Ebre. Doctoral thesis, Université des Sciences et Techniques du Languedoc, Montpellier.

Thiebaut, B. (1984). Variabilité génétique écologique du hetre 'commun' (Fagus sylvatica) dans les milieux, montagnards et de haute altitude en Europe. Doc. Ecol. pyr., III-IV, 513-21.

Tutin, T. G., Heywood, V. H., Burges, N. A., Valentine, D. H., Walters, S. M. \& Webb, D. A. (eds) (1964-80). Flora Europaea, 1-5. Cambridge University Press, Cambridge.

Villar, L. (1981). Impactos provocados en las zonas de montaña: $\mathrm{Su}$ gestión y conservación. Primer Curso de Ordenación del Territorio, 333-48. Escuela Técnica Superior de Agricultura, Lérida.

Villar, L. (1986). Sobre la conservación de los hayedos prepirenaicos y su importancia ecológica. Jornadas sobre la Conservación de la Naturaleza en España. Naturaleza y Sociedad, 259-63 Principado de Asturias, Oviedo.

Villar, L., Aseginolaza, C., Gómez, D., Montserrat, G., Romo, A. M. \& Uribe, P. (1988). Estudio sobre los hayedos prepirenaicos aragoneses. Flora, vegetación, cartografía y valor ecológico. Diputación General de Aragón e Instituto Pirenaico de Ecología, Jaca y Zaragoza (unpublished report).

Villar, L., Aseginolaza, C., Gómez, D., Montserrat, G., Romo, A. M. \& Uribe, P. (1990). Los hayedos prepirenaicos aragoneses: Fitosociología, fitotopografia y conservación. Acta Botanica Malacitana, 15, 283-95. 